\title{
European virulence survey for leaf rust in wheat
}

\author{
Ákos Mesterházy a*, Pavel Bartoš b ${ }^{a}$, Henriette Goyeau ${ }^{\mathrm{c}}$, Rients E. Niks ${ }^{\mathrm{d}}$, Maria CsöSZ ${ }^{\mathrm{a}}$, \\ Ole ANDERSEN**, Fedele CASUlli**, Mariana ITtu**, Elwyn Jones**, \\ Jacob MANisterski**, Klára MANNINGeR**, Marina PASQUinI**, Diego Rubiales**, \\ Gabriele SCHACHERMAYR**, Anna STRZEMBICKA**, László SzUnICS**, \\ Maria Todorova**, Otto UnGER**, Bernard VANCO**, Gyula VIDA**, Ursula WALther** \\ ${ }^{a}$ Cereal Res. Inst., 6701 Szeged, PO Box 391, Hungary \\ ${ }^{\mathrm{b}}$ Res. Inst. of Crop Production, Drnovska 507, 161-06 Praha-Ruzyne, Czech Republic \\ ${ }^{\mathrm{c}}$ Lab. Pathologie Végétale, 78850 Thiverval-Grignon, France \\ ${ }^{\mathrm{d}}$ Lab. voor Plantenveredeling, Wageningen University, PO Box 386, 6700 AJ Wageningen, The Netherlands
}

(Received 6 March 2000; revised 10 July 2000; accepted 29 August 2000)

\begin{abstract}
With standardised near isogenic line (NIL) differentials co-operators were able to present the first comprehensive virulence survey of the European wheat leaf rust population (1996-1999). The work included pathotype identification of 2608 isolates and field tests of NILs. $\operatorname{Lr} 9$ and $\operatorname{Lr} 19$ were very effective all over Europe. $\operatorname{Lr} 24, \operatorname{Lr} 25$, and $\operatorname{Lr} 28$ were also effective, but in some countries and locations substantial virulence frequencies were observed. In addition, the genes $L r 12, L r 13, L r 22 a, L r 34, L r 35$ and $L r 37$ were effective at the adult plant stage, but locally less so. In general, the indoor seedling tests and adult plant field tests showed good agreement. Virulence to $\operatorname{Lr} 1, \operatorname{Lr} 2 a, \operatorname{Lr} 24, \operatorname{Lr} 25, \operatorname{Lr} 28$ and Lr29 tended to increase in the period, for the other $L r$-genes the virulence frequency remained more or less stable. Among the 105 pathotypes identified none was clearly predominant in Europe.
\end{abstract}

\section{leaf rust / wheat / virulence / pathotypes / breeding for resistance}

Résumé - La situation en Europe pour la virulence de la rouille brune chez le blé. L'utilisation d'une gamme d'hôtes différentiels commune composée de lignées isogéniques (NIL) a permis aux auteurs de réaliser le premier inventaire exhaustif de la population européenne de rouille brune du blé (1996-1999). Deux mille six cent huit isolats ont été identifiés et les NIL ont été évaluées au champ. $\operatorname{Lr} 9$ et $\operatorname{Lr} 19$ se sont révélés efficaces dans toute l'Europe. $\operatorname{Lr} 24$, $L r 25$ et $L r 28$ ont également été efficaces, mais la fréquence des virulences correspondantes était non négligeable dans certains pays et certains lieux. Les gènes $\operatorname{Lr} 12, \operatorname{Lr} 13, \operatorname{Lr} 22 a, \operatorname{Lr} 34, \operatorname{Lr} 35$ et $\operatorname{Lr} 37$ ont été efficaces au stade adulte, excepté dans quelques lieux. En général, les résultats des tests au stade plantule en conditions contrôlées ont été cohérents

Communicated by Hanne Østergård (Roskilde, Denmark)

* Correspondence and reprints

akos.mesterhazy@mail.gk-szeged.hu

** Affiliations are in Appendix 
avec ceux obtenus au stade adulte au champ. Les fréquences de virulence sont demeurées stables au cours de la période étudiée, sauf pour $L r 1, L r 2 a, L r 24, L r 25$ et $L r 29$, dont les fréquences de virulence correspondantes tendaient à augmenter. Aucun des 105 pathotypes identifiés n'est apparu clairement dominant en Europe.

rouille brune / blé / virulence / pathotypes / sélection pour la résistance

\section{Introduction}

Wheat leaf rust is caused by the rust fungus Puccinia triticina [1]. Often used synonyms of this pathogen are $P$. tritici, $P$. recondita in short form, or $P$. recondita Rob. ex Desm. f. sp. tritici (Eriks.) Carl. Leaf rust is a major disease in most wheat growing areas [26]. More than 45 resistance genes to this disease have been identified up to now and to most of them the pathogen has developed virulence. Virulence surveys aim to detect new pathotypes and monitor shifts of pathotype frequencies, and to help breeders in proposing efficient resistance strategies to this disease. Such virulence survey work has a long tradition [12].

As stated by Zadoks and Bouwman [39], "race identification of wheat leaf rust has been messy for a long time" in Europe. This was caused by the lack of agreement on a standard differential set to discriminate between pathotypes. The situation was similar in America and Australia. Zadoks and Bouwman [39] noted that the international situation has much improved. McIntosh et al. [21] described the differential sets used in Australasia [24], North America [15, 18, 29], Middle America [2], South Africa [25], and India [22]. There are substantial differences between those sets. McIntosh et al. [21] did not mention a differential set used in Europe, although virulence surveys have been conducted in various countries for several years $[3-5,7,11,13,20,23,33,35]$. Each country or laboratory has used and maintained its own differential set based mostly on those used in the traditional American surveys, but according to local needs they added or deleted certain lines in the set.

Recently various European laboratories set up differential sets based on the 'Thatcher' Near
Isogenic Lines (NIL) series developed by Dyck in Canada (see Refs. in [21]). This was a first step towards standardisation of the virulence survey procedures.

The present paper reports (i) the implementation of a common procedure of virulence survey of wheat leaf rust and (ii) the determination of virulence and pathotype frequencies in Europe, by means of seedling and field tests.

\section{Materials and methods}

\subsection{Differential set}

Dr. Kolmer (Winnipeg, Canada) kindly provided the differential lines (Near-isogenic lines, NILs, in 'Thatcher' background) in 1994. At the Cereal Research Institute, Szeged, the lines were sown in $10 \mathrm{~m}$ long rows, $30 \mathrm{~cm}$ apart with $8 \mathrm{~cm}$ inter-plant spacing. All heads of 20 plants from each line were covered by paper bags before anthesis to prevent cross-pollination and only those were harvested of which the morphology and infection type (IT) were typical to the majority of plants in that line. These isolated and checked plants provided the basic seeds for distribution to the co-operators and further multiplication. In co-operation with Dr. Bartoš, some lines showing ambiguous IT were tested in the seedling stage to verify their identity.

Fifteen NILs were chosen to assemble a core differential set for use in all European countries. This set consisted of the 'Thatcher' NILs carrying the resistance genes $L r 1, L r 2 a, L r 2 b, L r 2 c, L r 3 a$, Lr9, Lr11, Lr15, Lr17, Lr19, Lr21, Lr23, Lr24, $L r 26$, and $L r 28$, respectively. These differentials are used also in other continents, their reaction is expressed in seedlings, and they were considered relevant to detect new virulences in the leaf rust 
population. Some co-operators included more than these 15 differential lines, especially the differentials carrying genes $L r 25, L r 29$ and $L r 30$.

\subsection{Isolate sampling and assessment of virulence}

The virulence survey was based on monopustule isolates. Each co-operator collected infected leaves from naturally infected plants of NILs and/or other wheat genotypes at several locations of their country. The urediospores from each leaf were transferred to a universally susceptible genotype and from the developing uredinia one or two monopustule-isolates were produced. In total 2608 monopustule isolates were tested, on average 655 per year (Tab. I). The samples represented populations from 12 European countries.

Spore suspensions or spore-talcum mixtures (1:3) of each isolate were applied onto the first leaf of seedlings of the differential NILs. After 24 or $48 \mathrm{~h}$ of $100 \%$ relative humidity under darkness, the seedlings were incubated at about $22 / 18{ }^{\circ} \mathrm{C}$ night/day. At some locations the temperatures were $3{ }^{\circ} \mathrm{C}$ higher or lower. Detached leaves were used only in Poland [9].

In Spain (1998) infected leaf samples were collected from several locations in the country and the spores of each sample were applied directly on the NILs in the greenhouse. In this case the virulence frequency is expressed relative to the total number of locations sampled (Tab. I). The data for other years and countries pertain to monopustule isolates as described above.

Seedling reactions were evaluated according to the Stakman scale (0-4) [34]. Infection types 2 and lower were interpreted as resistance/avirulence, IT $2+$ and above susceptibility/virulence.

\subsection{Adult plant tests}

For the field evaluation the core differential set was mostly grown as unreplicated single rows or hill plots usually near wheat breeding germplasm. The trial consisted of the differential set of lines, including the lines with adult plant resistance genes, and was planted at 1 to 14 locations per country (five countries) per year. For evaluation of the disease severity and type of the natural infection, the modified Cobb's scale [2] was used. This code consisted of the percentage of total leaf area, covered with uredia or necrotic flecks, and the IT, e.g. 5R, 40MS, or 40MR-MS. Some authors used a scale 1-9 (1 resistant, 9 susceptible). The moment of the evaluation varied among the co-operators. One or more ratings were made and the latest was usually made at milk ripening when the upper leaves were still green. In the tables the latest scores are given. Since no fungicides were applied, other leaf pathogens could influence assessment of the severity of infection by leaf rust.

Table I. Number of monopustule isolates or bulk samples tested in the European virulence survey, 1996-1999.

\begin{tabular}{cccccccccccccc}
\hline Years & \multicolumn{10}{c}{ Countries } \\
\hline & F & D & I & CZ & SK & GB & SP & H & PL & BG & RO & CH & \\
\hline 1996 & 54 & 128 & 77 & 89 & 63 & 0 & 0 & 33 & 175 & 110 & 0 & 72 & 801 \\
1997 & 92 & 92 & 61 & 44 & 30 & 4 & 7 & 100 & 205 & 52 & 0 & 0 & 687 \\
1998 & 62 & 41 & 68 & 30 & 11 & 0 & $13^{*}$ & 80 & 330 & 62 & 14 & 0 & $698^{*}$ \\
1999 & 69 & 58 & 0 & 33 & 35 & 45 & 16 & 0 & 152 & 0 & 14 & 0 & 422 \\
Sum & 277 & 319 & 206 & 196 & 139 & 49 & $16^{*}$ & 213 & 862 & 224 & 28 & 72 & $2608^{*}$ \\
\hline
\end{tabular}

$\mathrm{F}=$ France, $\mathrm{D}=$ Germany, $\mathrm{I}=$ Italy, $\mathrm{CZ}=$ Czech Republic, $\mathrm{SK}=$ Slovakia, GB = Great Britain, $\mathrm{SP}=\mathrm{Spain}, \mathrm{H}=\mathrm{Hungary}$, $\mathrm{PL}=$ Poland, $\mathrm{BG}=$ Bulgaria, $\mathrm{RO}=$ Romania, $\mathrm{CH}=$ Switzerland .

$0=$ no data from that year.

*Bulk samples from different locations, not considered in Table III. 


\section{Results}

\subsection{Virulence frequencies}

The virulence frequencies in each country for 1998 are presented in Table II. In that year the surveys covered 10 countries, so that the most comprehensive picture was obtained. In Table III the mean virulence frequencies over Europe are presented for each year.

$\operatorname{Lr} 9$ and $\operatorname{Lr} 19$ were the only genes that were fully effective all over Europe. In most countries the respective NILs remained free of infection. The results obtained for other years indicate that a significant virulence to $\operatorname{Lr} 9$ and $\operatorname{Lr} 19$ still does not occur in Europe.

Virulence to $\operatorname{Lr} 24$ was rare or absent in most countries, but relatively common in Bulgaria (30-50\%), and occurred also in Germany and Romania in 1998 (Tab. II). In 1999, the virulence frequency in Romania had increased to $86 \%$. These results suggest a new pathotype spreading into Europe from Bulgaria, as the virulence frequency in that country was high before it rose in Romania.

Table II. Percentage of isolates of Puccinia triticina virulent at the seedling stage on single-gene differential lines in European countries in 1998.

\begin{tabular}{|c|c|c|c|c|c|c|c|c|c|c|c|}
\hline \multirow{2}{*}{$\begin{array}{l}\mathrm{Lr} \\
\text { Genes }\end{array}$} & \multirow[t]{2}{*}{ Reference stock } & \multicolumn{10}{|c|}{ Countries } \\
\hline & & $\mathrm{F}$ & $\mathrm{D}$ & I & $\mathrm{CZ}$ & SK & $\mathrm{SP}^{*}$ & $\mathrm{H}$ & PL & BG & RO \\
\hline Lrl & Centenario/6*Thatcher R.L.6003 & 3.0 & 52.0 & 5.9 & 23.0 & 27.0 & 57.0 & 12.5 & 16.0 & 42.3 & 86.0 \\
\hline $\operatorname{Lr} 2 a$ & Webster/ 6*Thatcher , R.L.6016 & 0.0 & 58.6 & 1.5 & 23.0 & 9.0 & 36.0 & 15.0 & 11.0 & 9.6 & 79.0 \\
\hline $\operatorname{Lr} 2 b$ & Thatcher*6/Carina, R.L.6019 & 5.0 & 65.5 & 20.6 & 33.0 & 36.0 & 64.0 & 65.0 & 19.0 & 51.9 & 93.0 \\
\hline$L r 2 c$ & Thatcher*6/Loros, R.L.6025 & 97.0 & 82.8 & 95.6 & 100.0 & 100.0 & 79.0 & 97.5 & 42.0 & 96.2 & 100.0 \\
\hline $\operatorname{Lr} 3 a$ & Democrat/6* Thatcher, R.L.6002 & 69.0 & 31.0 & 45.6 & 100.0 & 91.0 & 64.0 & 65.0 & 97.0 & 100.0 & 93.0 \\
\hline $\operatorname{Lr} 9$ & Thatcher*6/Transfer, R.L.6010 & 0.0 & 0.0 & 0.0 & 0.0 & 0.0 & 0.0 & 0.0 & 0.0 & 0.0 & $-* *$ \\
\hline $\operatorname{Lr} 11$ & Thatcher*6/Hussar, R.L.6053 & 56.0 & 100.0 & 80.9 & 100.0 & 100.0 & 100.0 & 90.0 & 100.0 & 100.0 & 100.0 \\
\hline $\operatorname{Lr} 15$ & Thatcher*6/Kenya W1483, R.L.6052 & 11.0 & 51.7 & 13.2 & 77.8 & 73.0 & 21.0 & 55.0 & 95.0 & 25.6 & 100.0 \\
\hline Lr17 & Thatcher*6/ K.Lucero, R.L.6008 & 13.0 & 100.0 & 8.8 & 100.0 & 91.0 & 36.0 & 67.5 & 96.0 & 100.0 & 100.0 \\
\hline Lr19 & Thatcher*7/Tr.4 A.elong. & 0.0 & 0.0 & 0.0 & 0.0 & 0.0 & 0.0 & 0.0 & 0.0 & 0.0 & 0.0 \\
\hline $\operatorname{Lr} 21$ & Thatcher*6//RL 5406=Tetra C., R.L. 6043 & 3.0 & 79.3 & 97.0 & 100.0 & 100.0 & 86.0 & 87.5 & 98.0 & 100.0 & 100.0 \\
\hline $\operatorname{Lr} 23$ & Lee FL310/6*Thatcher, R.L. 6012 & 3.0 & 96.6 & 86.8 & 100.0 & 100.0 & 100.0 & 40.0 & 1.0 & 86.5 & 100.0 \\
\hline $\operatorname{Lr} 24$ & Thatcher*6/Agent, R.L.6064 & 0.0 & 6.9 & 0.0 & 0.0 & 0.0 & 0.0 & 0.0 & 0.0 & 46.2 & 14.0 \\
\hline $\operatorname{Lr} 25$ & Thatcher*7/Transec, R.L.6084 & $-*$ & 3.4 & 0.0 & - & - & 0.0 & - & 0.0 & - & - \\
\hline $\operatorname{Lr} 26$ & Thatcher*6/St-1.25, R.L.6078 & 18.0 & 48.3 & 38.2 & 90.0 & 73.0 & 7.0 & 80.0 & 98.0 & - & 100.0 \\
\hline $\operatorname{Lr} 28$ & Thatcher*6/C77.1, R.L.6079 & 0.0 & - & 8.8 & 0.0 & 0.0 & 21.0 & 0.0 & 69.0 & 44.2 & 86.0 \\
\hline $\operatorname{Lr} 29$ & Thatcher*6/CS7D/Ag\#11, R.L.6080 & - & 0.0 & 1.5 & - & - & 0.0 & - & 61.0 & 73.1 & - \\
\hline Lr30 & Thatcher*6/Terenzio, R.L.6049 & - & 69.0 & 92.6 & - & - & 64.0 & - & 96.0 & 100.0 & - \\
\hline Lr32 & Thatcher*7/3Ae. sq, R.L.6086 & - & 96.6 & - & - & - & 50.0 & - & 98.0 & - & - \\
\hline Lr33 & Thatcher*6/PI58548, R.L.6057 & - & 100.0 & - & - & - & 100.0 & - & 100.0 & - & - \\
\hline Lr34 & Thatcher*6/PI58548, R.L.6058 & - & - & - & - & - & 100.0 & - & 100.0 & - & - \\
\hline Lr37 & Thatcher*8/VPM1, R.L.6081 & - & 96.6 & - & - & - & 100.0 & - & 96.0 & - & - \\
\hline Lr38 & Thatcher*6/T7, R.L.6097 & - & 13.8 & - & - & - & 14.0 & - & 6.0 & - & - \\
\hline $\mathrm{Lr} 44$ & Thatcher*6/T. spelta 7831 & - & 75.9 & - & - & - & 100.0 & - & 94.0 & - & - \\
\hline$L r B$ & Thatcher*6/Carina, R.L.6051 & - & 100.0 & - & - & - & 43.0 & - & 98.0 & - & - \\
\hline$L r W$ & Thatcher*6/V336 & - & 6.9 & - & - & - & 0.0 & - & 30.0 & - & - \\
\hline
\end{tabular}

*Bulk populations, ** Cases not tested.

$\mathrm{F}=$ France, $\mathrm{D}=$ Germany, I = Italy, CZ = Czech Republic, SK = Slovakia, SP = Spain, H =Hungary, PL = Poland, BG = Bulgaria, $\mathrm{RO}=$ Romania . 
Virulence to $L r 25$ was also rare, but there are insufficient data to conclude about its distribution and spread over Europe. Relatively low virulence frequencies were observed in Italy (1997 and no virulence in 1998) and in Germany (1998). Also the virulence frequencies to $\operatorname{Lr} 38$ and $\mathrm{LrW}$ were low, and those genes, therefore, may also be of some interest for breeders.

Virulence frequencies to some $L r$-genes were variable among countries. For example, the frequencies of virulence to $\mathrm{Lr} 17$ and $\mathrm{Lr} 26$ were relatively low in south-west and southern Europe, but high in central and eastern Europe. For other virulences, e.g. the virulence to $L r 28$, the differences in frequency between countries and years were not easy to interpret. Part of the variation may be due

Table III. Percentage of isolates of Puccinia triticina virulent at the seedling stage on 18 single-gene differential lines in European countries in 1996-1999.

\begin{tabular}{lccccc}
\hline \multirow{2}{*}{ Lr genes } & \multicolumn{5}{c}{ Years } \\
\cline { 2 - 5 } & 1996 & 1997 & $1998 *$ & 1999 & \\
\hline Lr1 & 17.2 & 18.9 & 29.7 & 33.7 & 24.9 \\
Lr2a & 19.8 & 18.9 & 23.0 & 27.2 & 22.2 \\
Lr2b & 40.9 & 47.1 & 43.2 & 42.4 & 43.4 \\
Lr2c & 85.5 & 87.4 & 90.5 & 82.5 & 86.54 \\
Lr3a & 68.9 & 75.8 & 76.8 & 69.6 & 72.8 \\
Lr9 & 1.0 & 0.0 & 0.0 & 0.0 & 0.3 \\
Lr11 & 84.1 & 79.3 & 91.9 & 93.3 & 87.1 \\
Lr15 & 60.1 & 53.4 & 55.8 & 68.8 & 59.5 \\
Lr17 & 69.9 & 62.7 & 75.1 & 67.9 & 68.9 \\
Lr19 & 0.0 & 0.0 & 0.0 & 0.7 & 0.2 \\
Lr21 & 76.7 & 58.8 & 85.0 & 72.0 & 73.1 \\
Lr23 & 53.0 & 38.3 & 71.5 & 44.9 & 51.9 \\
Lr24 & 5.3 & 4.1 & 7.4 & 12.0 & 7.2 \\
Lr25 & 1.9 & 0.0 & 1.1 & 9.8 & 3.2 \\
Lr26 & 53.7 & 67.7 & 68.2 & 64.2 & 63.4 \\
Lr28 & 18.4 & 6.6 & 36.0 & 29.8 & 25.2 \\
Lr29 & 33.0 & 0.0 & 33.4 & 60.9 & 31.8 \\
Lr30 & 83.7 & 60.7 & 89.4 & 93.0 & 75.7 \\
Mean & $\mathbf{4 3 . 0}$ & $\mathbf{3 7 . 8}$ & $\mathbf{4 8 . 8}$ & $\mathbf{4 8 . 5}$ & $\mathbf{4 4 . 5}$ \\
No. of isolates & 801 & 687 & 698 & 422 & 2608 \\
\hline & & & & \\
\hline
\end{tabular}

* The bulk populations collected and tested in Spain are not included in this column. to the fact that some resistance genes (e.g. $\operatorname{Lr} 17$ and $L r 23$ ) may cause intermediate infection types to avirulent isolates [21], leading to difficulties in interpretation between co-operators.

The virulence frequencies to $L \mathrm{r} 2 c$ and $L r l 1$ were very high and often $100 \%$. In none of the countries these genes were sufficiently effective.

The frequency of virulence to $\operatorname{Lr} 34$ is hard to determine, since this gene does not cause a hypersensitive reaction [27]. In seedling tests the $\operatorname{Lr} 34$ would merely cause a slightly lower IT [21] or only a longer latent period [27]. It is therefore not surprising that the high IT on the Lr34 differential was interpreted as virulence of the isolates (Tab. II). Also Lr37 is considered as effective adult plant resistance gene [21].

The virulence frequencies to $L r 1, L r 2 a, L r 24$, $L r 25, L r 28$ and $L r 29$ showed a tendency to increase over the period 1996-1999 (Tab. III). The virulence frequencies to the other $L r$-genes were more stable (e.g. $L r 2 b, L r 3 a, L r 17$ ) or fluctuated in time (e.g. Lr30).

\subsection{Effectiveness of the Lr-genes in the field}

In the field test under natural infection, the disease severity on the differentials differed highly between countries and between locations within countries (Tab. IV). The data from 1996 and 1997 are not shown, as they were similar to those obtained in 1998 and 1999.

The leaf rust severity on Thatcher was in some cases lower than on some of the NILs.

$\operatorname{Lr} 9$ and $\operatorname{Lr} 19$ remained free of infection, although traces of infection were sometimes observed on the Lr19 differential. These genes were the most effective resistance genes in Europe.

Other seedling resistance genes that appeared to be widely effective in the field tests, were $L r 24$, $L r 25$, and $L r 38$. The effectiveness of $\operatorname{Lr} 28$ and Lr29 fluctuated strongly between locations and years.

The field evaluation also allowed evaluation of the effectiveness of resistance genes that are 
Table IV. Leaf rust severity in the field on single-gene differential lines in some European countries in 1998 and 1999.

\begin{tabular}{|c|c|c|c|c|c|c|c|c|c|}
\hline \multirow{3}{*}{ Lr Gene } & \multirow{3}{*}{$\begin{array}{c}\text { Romania } \\
1998 \\
\text { Fundulea }\end{array}$} & \multirow{2}{*}{\multicolumn{4}{|c|}{$\begin{array}{c}\text { Hungary } \\
1998\end{array}$}} & \multirow{3}{*}{$\begin{array}{c}\text { CH ** } \\
1998 \\
\text { Rkholz }\end{array}$} & \multirow{3}{*}{$\begin{array}{c}\text { GB } \\
1999 \\
\text { Aberyst. }\end{array}$} & \multicolumn{2}{|c|}{ PL } \\
\hline & & & & & & & & 1998 & 1999 \\
\hline & & Szeged & Marton. & Táplán & Budapest & & & $\mathrm{Kr} . * *$ & $\mathrm{Kr}$ \\
\hline Lrl & 70MS-S & 40MS-S & $60 \mathrm{~S}$ & 50R-MR & 0 & 2 & $18 \mathrm{MS}$ & 3 & 40MR \\
\hline $\operatorname{Lr} 2 a$ & 80MS-S & 40R-MR-MS & $70 \mathrm{~S}$ & 80MS & 0 & 4 & $18 \mathrm{~S}$ & 3 & $30 \mathrm{MS}$ \\
\hline$L r 2 b$ & 80MS-S & $-^{\#}$ & $50 \mathrm{~S}$ & 80MR-MS & $30 \mathrm{~S}$ & 5.5 & $25 \mathrm{~S}$ & 6 & $60 \mathrm{MS}$ \\
\hline$L r 2 c$ & $80 \mathrm{~S}$ & 60MS-S & $40 S$ & 80MS & 40-50MS & 6 & $35 \mathrm{~S}$ & 6 & $50 \mathrm{MS}$ \\
\hline Lr3 & $80 \mathrm{~S}$ & 80MR-MS-S & $50 \mathrm{~S}$ & $30 \mathrm{R}$ & $20 \mathrm{MS}$ & 6 & $45 \mathrm{~S}$ & 7 & $60 \mathrm{MS}$ \\
\hline Lr3bg & $40 \mathrm{MS}$ & 40MR, S & $80 \mathrm{~S}$ & 80MS-S & 30-40MS & 6 & $45 \mathrm{~S}$ & 5 & 70MS \\
\hline Lr3ka & $80 \mathrm{~S}$ & 20R-MR & $70 \mathrm{~S}$ & tR-MR & 30-40MS & 5 & $45 \mathrm{~S}$ & 6 & 40MS \\
\hline $\operatorname{Lr} 9$ & - & 0 & 0 & 0 & 0 & 1 & 0 & 1 & - \\
\hline Lrlo & $80 \mathrm{~S}$ & 30MR-MS & $20 \mathrm{~S}$ & 60MR-MS & 10MR-MS & 5 & - & 6 & 30MR \\
\hline Lrl1 & $60 \mathrm{MS}$ & 30MR & $30 \mathrm{~S}$ & - & 5MR-MS & 4.5 & $45 \mathrm{~S}$ & 6 & $50 \mathrm{MS}$ \\
\hline $\operatorname{Lr} 12-\mathrm{A}^{\dagger}$ & 70MS-S & 20MR-MS & 1R-40MS & 30R-MR & 0 & 3 & - & 3 & 30MR \\
\hline Lrl3-A & $80 \mathrm{~S}$ & 40R-MR & 0 & 30R-MR & t R-MR & 3 & $30 \mathrm{~S}$ & 4 & $50 \mathrm{MS}$ \\
\hline$L r 14 a$ & $80 \mathrm{~S}$ & 40MR-MS-S & - & 40MS & $50 \mathrm{~S}$ & 5.5 & $50 \mathrm{~S}$ & 6 & $60 \mathrm{MS}$ \\
\hline$L r 14 b$ & $70 \mathrm{MS}$ & $10 \mathrm{MR}$ & $15 \mathrm{MS}$ & 40MR-MS & 10MR-MS & 3.5 & - & 5 & 70MS \\
\hline Lrl5 & $80 \mathrm{~S}$ & 20MR-MS & $1 \mathrm{R}-40 \mathrm{~S}$ & 80MS & 40-50MS-S & 6 & $50 \mathrm{~S}$ & 5 & $70 \mathrm{~S}$ \\
\hline Lr16 & $80 \mathrm{~S}$ & 40MR-MS & $50 \mathrm{~S}$ & $60 \mathrm{MS}$ & 30MS-S & 4.5 & - & 5 & $50 \mathrm{MS}$ \\
\hline $\operatorname{Lr} 17$ & - & $10 \mathrm{MR}$ & $1 \mathrm{R}$ & 20R-MR & t MS & 3 & $35 \mathrm{MR}$ & 6 & $60 \mathrm{MS}$ \\
\hline $\operatorname{Lr} 18$ & $30 \mathrm{MS}$ & $10 \mathrm{R}$ & $0-40 \mathrm{MR}$ & 10R-MR & t MR-MS & 2.5 & - & 3 & $10 \mathrm{R}$ \\
\hline $\operatorname{Lr} 19$ & OR & $\mathrm{tMR}$ & t R & 0 & 0 & 1 & $\mathrm{tR}$ & 1 & 0 \\
\hline $\operatorname{Lr} 20$ & 30MR-MS & 10R-MR & $0-10 \mathrm{MR}$ & 40MR & t MR-MS & 2 & $35 \mathrm{~S}$ & 5 & 30MS \\
\hline Lr21 & 70MS-S & 10MR & 0 & 60MR-MS & 0 & 2.5 & $30 X$ & 6 & $50 \mathrm{~S}$ \\
\hline$L r 22 a-\mathrm{A}$ & $50 \mathrm{MS}$ & $\mathrm{tMR}$ & 0-30 MR & 10R-MR & 0 & 3.5 & - & 2 & $10 \mathrm{MR}$ \\
\hline $\operatorname{Lr} 23$ & $80 \mathrm{~S}$ & 2R-MR & $1 \mathrm{R}$ & 40MS & 20MR-MS & 3 & $40 X$ & 3 & $2 \mathrm{R}$ \\
\hline $\operatorname{Lr} 24$ & $\mathrm{OR}$ & t MR & 0 & $\mathrm{t} M R$ & t MR & 1 & 0 & 1 & 0 \\
\hline $\operatorname{Lr} 25$ & - & t MR & 0 & 0 & 10-30MR-MS & 1 & - & 4 & 0 \\
\hline $\operatorname{Lr} 26$ & $80 \mathrm{~S}$ & 5R-MR & $80 \mathrm{~S}$ & $60 \mathrm{MS}$ & $30 \mathrm{MS}$ & 4.5 & $45 \mathrm{~S}$ & 7 & $60 \mathrm{MS}$ \\
\hline $\operatorname{Lr} 28$ & $20 \mathrm{MR}$ & $5 \mathrm{R}$ & $0-5 \mathrm{R}$ & $80 \mathrm{MS}$ & 0 & 1 & $15 \mathrm{R}$ & 5 & $10 \mathrm{~S}$ \\
\hline $\operatorname{Lr} 29$ & 90MS-S & 30MR-MS-S & 0 & $\mathrm{t} \mathrm{MR}$ & 0 & 1 & - & 3 & 0 \\
\hline Lr30 & $90 \mathrm{~S}$ & $5 \mathrm{MR}$ & $60 S$ & 80MS & $30 \mathrm{MS}$ & 4.5 & - & 7 & 20MR \\
\hline Lr32 & 80MS-S & 10R-MR & $0(50 \mathrm{~S})$ & 30R-MR & $\mathrm{t} \mathrm{MR}$ & 3 & - & 5 & 20MR \\
\hline Lr33 & 80MS-S & 40MS & $30 \mathrm{MS}$ & 80MS & 0 & 5 & - & 7 & $60 \mathrm{MS}$ \\
\hline Lr34-A & 80MS-S & 20MR-MS & $0(5 \mathrm{MR})$ & $60 \mathrm{MS}$ & $\mathrm{t} \mathrm{MR}$ & 4.5 & - & 3 & $10 \mathrm{MR}$ \\
\hline Lr35-A & $\mathrm{tMS}$ & 0 & $0-50 \mathrm{R}$ & - & $\mathrm{t} \mathrm{MR}$ & 1 & - & 3 & $5 \mathrm{R}$ \\
\hline Lr37-A & 50MR-MS & $5 \mathrm{MR}$ & 0 & 10R-MR & $\mathrm{t} \mathrm{MR}$ & 1 & $35 \mathrm{MR}$ & 2 & 0 \\
\hline $\operatorname{Lr} 38$ & OR & 0 & 0 & - & 0 & 1 & - & 3 & $10 \mathrm{MR}$ \\
\hline $\mathrm{Lr} 44$ & 30MR-MS & $5 \mathrm{MR}$ & $3 \mathrm{R}$ & $60 \mathrm{MR}$ & $20 \mathrm{MS}$ & 1 & - & 5 & $30 \mathrm{~S}$ \\
\hline $\operatorname{LrB}$ & - & 60MS-S & $1 \mathrm{R}$ & $40 \mathrm{MS}$ & $30 \mathrm{MS}$ & 8 & - & 2 & 40MS \\
\hline$L r W$ & - & 40MS & 0 & - & 0 & 2.5 & - & 3.5 & 20MR \\
\hline Thatcher & $50 \mathrm{~S}$ & $70 \mathrm{~S}$ & $60 \mathrm{~S}$ & $80 \mathrm{~S}$ & 80-100S & 5.5 & - & 5 & 80-100S \\
\hline
\end{tabular}

* Scoring was made using the modified Cobb's scale, $\mathrm{S}=$ susceptible, $\mathrm{MS}=$ moderately susceptible, $\mathrm{MR}=$ moderately resistant, and $\mathrm{R}=$ resistant. $\mathrm{X}$ intermediate $\mathrm{IT}, \mathrm{t}=$ traces.

** Switzerland, Zürich-Reckenholz, and Poland, Krakow, scoring was made on a 1-9 scale, 1 indicating no symptoms.

-: no data available, 0: no infection recorded.

${ }^{\dagger}$-A: resistance genes that are predominantly effective in the adult plant stage [21]. 
known to be expressed primarily or only in the adult plant stage. Of these adult plant resistance genes, Lr35 was the most widely and strongly effective. The effectiveness of the other adult plant resistance genes ( $L r 12, L r 13, L r 22 a, L r 34$ and $L r 37)$ appeared to vary among locations. Most of these genes normally do not cause complete resistance, but intermediate types of infection and less protection at high temperatures [21].

\subsection{Pathotype composition}

Pathotype composition was not determined in all countries and all years. The most comprehensive data were obtained in 1998 (Tab. V). The total number of pathotypes identified over five countries in that year was 105 . The countries had very few pathotypes in common. A predominant pathotype, accounting for 16 to $30 \%$ of the population, could be identified in each country, except in Bulgaria where the population was composed of many pathotypes, each with a frequency lower than $6 \%$. The predominant pathotypes were rather simple in France and Italy (1 to 4 virulence genes), whereas they were complex (up to 13 virulence genes) in Poland, Bulgaria and Hungary. There were hardly any or no predominant pathotypes in common between countries. The data indicate great genetic diversity in the European population of the wheat leaf rust fungus, especially in south-eastern Europe.

Table V. Frequency (as percentage) of the dominant, and several other, pathotypes of Puccinia triticina among the 105 pathotypes identified in five European countries in 1998.

\begin{tabular}{|c|c|c|c|c|c|}
\hline \multirow[t]{2}{*}{ Virulent on lines with $L r$ genes } & \multicolumn{5}{|c|}{ Countries* } \\
\hline & $\mathrm{F}$ & $\mathrm{H}$ & $\mathrm{I}$ & BG & PL \\
\hline $2 c$ & 12.0 & - & - & - & - \\
\hline $2 c, 21,23$ & - & - & 16.2 & - & - \\
\hline $2 c, 11$ & 12.0 & - & - & - & - \\
\hline $2 c, 11,21,23$ & - & 12.5 & 29.4 & - & - \\
\hline $3,11,15,17,21,26$ & - & - & - & 2.0 & 17.1 \\
\hline $3,11,15,17,21,26,28$ & - & - & - & - & 25.4 \\
\hline $2 c, 3$ & 16.0 & - & - & - & - \\
\hline $2 c, 3,11$ & 16.0 & - & - & - & - \\
\hline $2 c, 3,11,21,23,26$ & - & 2.5 & 11.8 & - & - \\
\hline $2 c, 3,11,15,17,21,26,28$ & - & - & - & 2.0 & 14.6 \\
\hline $1,2 c, 3,11,17,21,23,26$ & - & - & - & 5.9 & - \\
\hline $1,2 c, 3,11,17,21,23,28$ & - & - & - & 5.9 & - \\
\hline $1,2 c, 3,9,11,15,17,21,23,24,26,28$ & & & & 2.0 & \\
\hline $2 b, 2 c, 3,11,17,21,23$ & - & - & - & 5.9 & - \\
\hline $2 b, 2 c, 3,11,17,21,23,26$ & - & - & - & 5.9 & - \\
\hline $2 b, 2 c, 3,11,15,17,21,26$ & - & 22.5 & - & - & 1.5 \\
\hline $2 a, 2 b, 2 c, 11,15,17,21,26$ & & 5.0 & & & 3.7 \\
\hline $1,2 a, 2 b, 2 c, 3,11,15,17,21,26$ & - & 10.0 & - & - & - \\
\hline $1,2 a, 2 b, 2 c, 3,11,15,17,21,23,26,28$ & & & & 2.0 & \\
\hline $1,2 a, 2 b, 2 c, 3,11,15,17,21,23,24,26,28$ & & & & 2.0 & \\
\hline Total & 56.0 & 52.5 & 57.4 & 33.6 & 62.3 \\
\hline
\end{tabular}

*F= France, $\mathrm{H}=$ Hungary, I= Italy, $\mathrm{BG}=$ Bulgaria, $\mathrm{PL}=$ Poland. 


\section{Discussion}

This paper reports on the first attempt to set up a comprehensive virulence survey of the wheat leaf rust pathogen in Europe. Major improvements were the agreement of a standardized differential set and a common seed stock of NILs. Nevertheless, differential lines that were not true to type were still used locally. The standardisation and the international co-operation enabled detection of such erroneous materials, and the rectification of them.

\subsection{Sampling}

The host genotypes on which the isolates are collected influence the survey results. If the isolates are collected from plants with effective genes the survey will of course lead to higher frequencies of the corresponding virulent pathotypes. Since a major purpose of virulence surveys is to provide information on new virulences to breeders, it is justified to sample on cultivars with certain commercially interesting $L r$-genes. A more representative picture of the structure of the leaf rust population is obtained when samples are collected from universally susceptible wheat lines, preferably collected by mobile spore traps [32]. By such a sampling new pathotypes important for the breeding have a lower chance of being identified. The present survey had not been standardised with respect to the sampling strategy, which may partly explain differences in virulence frequencies among countries. To serve breeders, future surveys should be carried out on isolates collected on cultivars or breeding lines for which new pathotype development is particularly relevant (viz. $\operatorname{Lr} 9, \operatorname{Lr} 19, \operatorname{Lr} 24$, Lr25 and $L r 28$ ).

\subsection{Virulence frequencies}

The 2608 isolates analysed give a comprehensive picture of the virulence frequencies in the European wheat leaf rust fungus population. The results of the field test agreed quite well with those of the seedling tests. Both tests indicated that the frequencies of virulence to genes $\operatorname{Lr} 9, \operatorname{Lr} 19, \operatorname{Lr} 24$, $L r 25$ and $L r 28$ are low in large parts of Europe, or even in the whole of Europe. The same is probably true for virulence to the adult plant resistance gene Lr35. It is relevant to note that, as far it is known, none of these genes is currently deployed on a large scale in European wheat cultivars [38].

The genes to which virulence is rare in Europe are more or less the same as reported in other continents $[6,8,14,21,26,28,31,36$, and 37]. Among the exceptions is $L r 24$, which is widely ineffective in North and South America and South Africa, but effective in Australia and the Indian subcontinent [22] and Europe. Maybe the most striking difference is the apparently frequent occurrence of virulence against $L r 21$. Virulence to this gene has been reported to occur locally at low frequencies in Europe [23] and elsewhere (HuertaEspino, cited in [21]). Our data suggest that virulence to this gene is widespread and common now (Tabs. II and III). For this gene, it is, however, possible that in some situations avirulent isolates are interpreted as virulent in seedling tests [21]. Our results also suggest that virulences to $L r 24$ and Lr25 are not as rare as in a previous survey [23].

The resistance genes that were postulated to be most common in the modern European winter wheat germplasm, were $\operatorname{Lr} 3 a, \operatorname{Lr} 10, \operatorname{Lr} 13, \operatorname{Lr} 14 a$, Lr20, Lr26 and Lr37 [38]. To most of these genes the virulence frequencies appeared to be high (Lr3a, Lr26, Tab. II) and/or the level of protection in the field was low (Lr10, LrI4a, Tab. IV). In the case of $L r 26$ the virulence frequency is especially high in eastern Europe, where cultivars carrying $L r 26$ were very popular. The gene $L r 37$ is the most effective of the presently deployed resistance genes in Europe.

The average frequency of virulences appeared to increase slightly for the $L r$-genes included in the surveys (43\% in 1996 to $49 \%$ in 1999). However, the period of the study is too short, and the sampling methods not sufficiently standardised to draw firm conclusions on an overall virulence increase in Europe. 


\subsection{Value of field tests}

The field tests provide another approach to survey the occurrence of virulences. Most survey papers report on virulence frequencies obtained in seedling tests. Only a few attempts have been made before to use field tests in order to evaluate virulences in rust populations [21].

The NILs were sown mostly in breeding nurseries where the number of pathotypes is expected to be much higher than in commercial fields, because of the much larger genetic variation in resistance genes present in the nurseries. As the differential set is exposed to spores of all different local pathotypes in different parts of the countries, the infection severity indicates the general protective ability of the respective $L r$-genes under field conditions. However, the observation of a lower severity on the susceptible check Thatcher, as compared to some NILs with $L r$ genes, suggests that this field testing does not permit a precise quantitative ranking of the efficiency of the genes. The good general agreement between the field tests (Tab. IV) and the virulence surveys on seedlings (Tab. III), the possibility of the field test to assess the effectiveness of genes for adult plant resistance, and the low labour input required for field tests, imply that field tests are an efficient alternative to seedling tests.

\subsection{Adult plant resistance}

In all four years of field tests, $\operatorname{Lr} 35$ and $\operatorname{Lr} 37$ gave a better protection than the other adult plant resistance genes. Most adult plant resistance genes cause incomplete types of resistance. Avirulent pathotypes would merely cause lower infection levels than virulent pathotypes, and such differences are, in this type of test, much harder to detect than for (a)virulences to qualitative types of resistance. Winzeler et al. [38] reported that among the winter wheat cultivars with the highest susceptibility to wheat leaf rust, some were probable carriers of $\mathrm{Lr} 13$, indicating low effectiveness of this gene. It is unclear whether the variation in performance of Lrl3-carrying cultivars is due to variation for corresponding virulence in the local pathogen populations, or due to interactions between $\operatorname{Lrl} 3$ with genes in the genetic background. It has been reported, for example, that combinations between Lr13 and Lr34 result in very high levels of resistance, due to synergism between both genes [10, 30].

\subsection{Pathotype composition}

The 1998 data from five countries indicate a great diversity in pathotype composition between countries. Altogether 105 pathotypes were identified on a total sample of 592 isolates. This implies that on average each pathotype was represented by only 5 to 6 isolates. Especially in eastern Europe the variation in the pathogen population and the average number of virulence factors per pathotype were greater than in central, south and western Europe. In our survey, the pathotype composition varied greatly between years in the same country, as has been reported for France, Italy and Hungary $[7,11,20]$. Such diversity between years and regions has been reported also for the US [19].

Commonly the predominant pathotypes in one country were not found in any other country. This result seems in contrast with the main conclusion of Park and Felsenstein [23] who found 4 predominant and widespread pathotypes across western Europe. These pathotypes were very similar to those present in former Czechoslovakia in the past 20 years. Their results suggested that migration across Europe resulted in some common features in pathotype composition between European countries. However, their survey [23] concentrated on western Europe and did not cover the whole continent. A survey in the USA [17] demonstrated that on a continent, several subpopulations can be distinguished, each with their own pathotype composition, but similarities can be found [16].

\subsection{Breeding aspects}

It is of interest that none of the widely effective $L r$-genes are exploited so far in commercially grown wheat cultivars in the countries covered by 
this study. Some of these genes, however, are reputed to be associated with inferior agronomic performance. $\operatorname{Lr} 19$ is associated with undesirable yellow-pigmented flour [21], $L r 25$ with poor performance [21] and also $L r 9$ may have adverse sideeffects. A derivative of the Swiss cultivar 'Arina' in which the $\operatorname{Lr} 9$ gene had been introduced, yielded significantly less than the original version of 'Arina' [Winzeler, pers. comm. 1999]. Despite the possible risks, alien genes are now widely used in crossing programs $[21,36]$.

Pyramiding resistance genes has been suggested already a long time ago (see citations in [21] and [26]). In fact, many cultivars already contain more than one resistance gene to leaf rust $[21,38]$. However, the strategy would only be effective in cases where the virulence frequencies to each of the $L r$ genes are negligible. Our study indicates some candidate genes that could be used for such a pyramiding, possibly in combination with genes like Lr34 that tends to enhance the effects of genes that would result in incomplete resistance, if applied alone.

Acknowledgements: The authors are indebted for the help of COST Action 817 for providing the framework for the cooperation in the leaf rust virulence survey project. We thank, for the help and encouragement of the project leader, Dr. Hanne Østergård, Denmark. We express our particular thanks to Dr. J.A. Kolmer, Canada, for sending the basic seed stocks for the work.

\section{Appendix}

Ole ANDERSEN: Sejet Plant Breeding, Norremrksvej 67, Sejet, 8700 Horsens, Denmark

Fedele Casulli: Dept. Plant Pathology, Univ. Bari, Via Amendola 165/A, 70126 Bari, Italy

Mariana ITTU: Res. Inst. For Cereals and Industrial Crops, 8264 Fundulea, Romania

Elwyn Jones: Inst. Grassland and Environ. Res., Plas Gogerddan, Aberystwyth, Dyfed SY23 3EB, UK

Jacob MANISTERSKI: Inst. For Cereal Crops Improvement, Thu, Israel

Klára MANnINGER: Plant Protection Institute, PO Box 102, 1525 Budapest, Hungary

Marina PASQUINI: Exper. Inst. for Cereal Research, Via Cassia 176, 00191 Roma, Italy

Diego Rubiales: Inst. Agricultura Sostenible (CSIC),
Alameda del Obsipo s/n, Apartado 4084, 14080 Córdoba, Spain

Gabriele ScHACHERMAYR: Swiss Federal Res. Stat. for Agroecol. and Agric., Reckenholzstr. 191/211, 8046 Zürich-Reckenholz, Switzerland

Anna STRZEMBICKA: Inst. Hodowli i Aklimatyzacji Roslin, ul. Zawila 4, 30-423 Krakow, Poland

László Szunics: Agricultural Res. Inst., 2462 Martonvásár, Hungary

Maria Todorova: Plant Protection Institute, 2230 Kostinbrod, Bulgaria

Otto UNGER: Nordsaat Saatzucht., Hauptstr. 1, 38895 Böhnhausen, Germany

Bernard VANCO: Research Institut of Plant Production, Bratislavsska 122, 921-68 Piestany, Slovakia

Gyula VIDA: Agricultural Res. Inst., 2462 Martonvásár, Hungary

Ursula Walther: Fed. Cen. Breed. Cult. Pl., Inst. Epid. Resistance, Theodor-Roemer Weg 4, 06449 Aschersleben, Germany

\section{References}

[1] Anikster Y., Bushnell W.R., Eilam T., Manisterski J., Roelfs A.P., Puccinia recondita causing leaf rust on cultivated wheats, wild wheats and rye, Can. J. Bot. 75 (1997) 2082-2090.

[2] Anonymous, CIMMYT Report on Wheat Improvement, Mexico D.F., p. 115, 1976.

[3] Bartos P., Huszar J., Virulence of the wheat leaf rust population in Slovakia in 1996, Biológia (Bratislava) 53 (1998) 99-105.

[4] Bartos P., Stuchlikova E., Wheat leaf rust races/pathotypes in the Czech Republic in 1997-1998, Plant Prot. Sci. 35 (1999) 51-56.

[5] Bartos P., Stuchlikova E., Hanusova R., Physiologic specialization of wheat leaf rust (Puccinia persistens Plow. var. triticina (Eriks.) Urban et Markova) and stem rust (Puccinia graminis Pers. subsp. graminis) in the Chech and Slovak Republics in the years 1991-1993), Genetika a Slechteni 30 (1994) 253-267.

[6] Boskovic M.M., Boskovic V.J., Jerkovic J., Evaluation of wheat genotypes for differentiating pathotypes of Puccinia recondita tritici, Proc. of the 9th Cereal Rust \& Powdery Mildews Conference, 2-6 Sept. Lunteren, The Netherlands, 1996, p. 134 (Abstr.). 
[7] Casulli F., Pasquini M., Pathogenicity of Puccinia recondita f. sp. tritici in Italy from 1993 to 1996, Phytopathol. Mediterranea 27 (1998) 51-57.

[8] Chen W.Q., Qin Q.M., Chen Y.L., Yan S.B., Virulence dynamics of Puccinia recondita f. sp. tritici in China during 1992-1996, Acta Phytopathol. Sinica 28 (1998) 101-106.

[9] Felsenstein F.G., Hsam S.L.K., Zeller F.J., Distribution of virulence of Erysiphe graminis f. sp. avenae in western Europe, Proc. of the 9th Cereal Rust and Powdery Mildews Conference, 2-6 Sept. Lunteren, The Netherlands, 1996, p. 136 (Abstr.).

[10] German S.E., Kolmer J.A., Effect of gene Lr34 in the enhancement of resistance to leaf rust of wheat, Theor. Appl. Genet. 84 (1992) 97-105.

[11 Goyeau H., de Vallavieille-Pope C., Population structure and sampling of Puccinia recondita f. sp. triti$c i$ in France during 1993-1995, Proc. of the 9th Cereal Rust and Powdery Mildews Conference, 2-6 Sept. Lunteren, The Netherlands, 1996, p. 136 (Abstr.).

[12] Johnston C.O., Maines E.B., Studies on physiologic specialisation in Puccinia triticina. U.S. Dept. Agric., Tech. Bull. 313 (1932) 1-22.

[13] Jones E.R.L., Brown rust of wheat. UK Cereal Pathogen Virulence Survey 1998, Ann. Rep., 1999, pp. 34-42.

[14] Kolmer J.A., Physiologic specialization of Puccinia triticina in Canada, 1997, Plant Dis. 83 (1999) 194-197.

[15] Kolmer J.A., Liu J.Q., Physiologic specialization of Puccinia recondita $\mathrm{f}$. $\mathrm{sp}$. tritici in Canada in 1995, Can. J. Plant Pathol. 19 (1997) 166-170.

[16] Kolmer J.A., Liu J.Q., Virulence and molecular polymorphism in international collections of the wheat leaf rust fungus Puccinia triticina, Phytopathology 90 (2000) 427-436.

[17] Leonard K.J., Roelfs A.P., Long D.L., Diversity of virulence within and among populations of Puccinia recondita $\mathrm{f}$. sp. tritici in different areas of the United States, Plant Dis. 76 (1992) 500-504.

[18] Long D.L., Kolmer J.A., A North American system of nomenclature for Puccinia recondita f. sp. tritici, Phytopathol. 79 (1989) 525-529.

[19] Long D.L., Leonard K.J., Roberts J.J., Virulence and diversity of wheat leaf rust in the United States in 1993 to 1995, Plant Dis. 82 (1998) 1391-1400.

[20] Manninger K., Physiologic specialization of Puccinia triticina in Hungary during 1994-1998. Workshop on Disease Resistance and Cereal Leaf
Pathogens beyond the Year 2000, COST Action 817, 11-12 November, Martina Franca, Italy, 1999, p. 45 (Abstr.).

[21] McIntosh R.A., Wellings C.R., Park R.F., Wheat Rusts - an Atlas of Resistance Genes, Kluwer Acad. Publ., Dordrecht, 1995.

[22] Nagarajan S., Nayar S.K., Bahadur P., Kumar J., Wheat Pathology and Wheat Improvement. Azad Hind Stores: Chandrigarh, India, 1986.

[23] Park R.F., Felsenstein F.G., Physiological specialization and pathotype distribution of leaf rust of wheat in Western Europe, 1995, Plant Pathol. 47 (1998) $157-164$.

[24] Park R.F., Wellings C.R., Pathogenic specialization of wheat rusts in Australia and New Zealand in 1988 and 1989, Australas. Plant Pathol. 21 (1992) 61-69.

[25] Pretorius Z.A., Le Roux J., Occurrence and pathogenicity of Puccinia recondita f. sp. tritici on wheat in South Africa during 1986 and 1987, Phytolactica 20 (1988) 349-352.

[26] Roelfs A.P., Sing R.P., Saari E.E., Boers L.H.M., Rust diseases of wheat: Concepts and methods of disease management. Mexico, D.F. CIMMYT, 81 p., 1992.

[27] Rubiales D., Niks R.E., Characterization of Lr34, a major gene conferring nonhypersensitive resistance to wheat leaf rust, Plant Dis. 79 (1995) 1208-1212.

[28] Saini R.G., Livinder K., Mandeep K., Adult plant leaf rust (Puccinia recondita tritici) resistance on known $L r$ genes against three virulence variants of pathotype 77 from Indian sub-continent, Indian J. Agric. Sci. 68 (1998) 776-779.

[29] Samborski D.J., Wheat leaf rust, in: Roelfs A.P., Bushnell W.R. (Eds.), The cereal rusts. Vol. II, Academic Press, Orlando, 1985, pp. 39-59.

[30] Sawhney R.N., The role of Lr34 in imparting durable resistance to wheat leaf rust through gene interaction, Euphytica 61 (1992) 9-12.

[31] Sawhney R.N., Sharma I.B., Rajesh K., Assessment and exploitation of genetic variation for resistance to Puccinia recondita for stabilizing wheat production, Indian J. Genet. Plant Breed. 58 (1998) 251-262.

[32] Schwarzbach E., A high throughput jet trap for collecting mildew spores on living leaves, Phytopathol. Z. 94 (1979) 165-171. 
[33] Strzembicka A., Virulence of Puccinia recondita f. sp. tritici in Poland, J. Appl. Genet. 38B (1997) 101-105.

[34] Stakman E.C., Stewart D.M., Loegering W.Q., Identification of physiologic races of Puccinia graminis var. tritici, Agr. Re. Service E 617 (USDA), Washington D.C., ARS 617, 53 p., 1962.

[35] Todorova M., Pathotype specialization of Puccinia recondita f. sp. tritici in Bulgaria during 1973-1993, Cereal Rusts and Powdery Mildews Bull. 24 (1996) 54-59.

[36] Tomar S.M.S., Menon M.K., Introgression of alien genes for leaf rust (Puccinia recondita) resistance into bread wheat (Triticum aestivum) cultivars, Indian J. Agric. Sci. 68 (1998) 675-681.
[37] Watkins J.E., Rutledge S.S., Baenziger P.S., Youngquist W., Physiologic specialization of Puccinia recondita f. sp. tritici in Nebraska during 1995 and 1996, Plant Dis. 82 (1998) 679-682.

[38] Winzeler M., Mesterházy A., Park R.F., Bartos P., Csõsz M., Goyeau H., Ittu M., Jones E., Löschenberger F., Manninger K., Pasquini M., Richter K., Rubiales D., Schachermayr G., Strzembicka A., Trottet M., Unger O., Vida G., Walther U., Resistance of European winter wheat germplasm to leaf rust, Agronomie 20 (2000) 783-792.

[39] Zadoks J.C., Bouwman J.J., Epidemiology in Europe, in: Roelfs A.P., Bushnell W.R. (Eds.), The Cereal Rusts, Vol. II. Academic Press: Orlando, Florida, USA, 1985, pp. 329-369. 